\title{
Hydrocarbon reservoir delineation using simultaneous and elastic impedance inversions in a Niger Delta field
}

\author{
Oluwakemi Y. Adesanya ${ }^{1}$ (D $\cdot$ Lukumon Adeoti $^{1} \cdot$ Kayode F. Oyedele $^{1} \cdot$ Itsemode P. Afinotan $^{2} \cdot \operatorname{Taiwo~Oyeniran~}^{1}$. \\ Saheed Alli ${ }^{1}$
}

Received: 8 May 2020 / Accepted: 16 May 2021 / Published online: 15 June 2021

(c) The Author(s) 2021

\begin{abstract}
The global energy demand is increasing while production from mature fields is drastically reducing consequently, oil and gas industries are expanding activities into more challenging areas. The inability of the traditional seismic data to properly delineate hydrocarbon reservoirs from subtle seismic features in 'Sandfish' field located offshore, Niger Delta informed the use of simultaneous and elastic impedance inversion. The elastic and derived volumes from seismic inversion would reduce risk, enhance hydrocarbon discovery and optimize development plans in the study area. Four 'Sandfish' (Sfn) wells (Sfn-01, Sfn-02, Sfn-04 and Sfn-05), check-shots and 3D seismic data of five angle stacks $\left(6-12^{\circ}, 12-18^{\circ}, 18-26^{\circ}, 26-32^{\circ}\right.$ and $\left.32-42^{\circ}\right)$ were used in the study. Low frequency $(0-2 \mathrm{~Hz})$ models were generated from interpolation of high-cut-filtered compressional wave velocity log (P-sonic), shear wave velocity log (S-sonic) and density log guided by interpreted four seismic horizons. The low frequency models broaden the spectrum of the elastic volumes and also served as inversion constraints. The five partial angle stacks varying from $6-42^{\circ}$ were simultaneously inverted using Jason's Rock-Trace ${ }^{\circledR}$ inversion software which iterated trial inversions until the model sufficiently matched the seismic data. The near $\left(6-12^{\circ}\right)$ angle and far-far $\left(32-42^{\circ}\right)$ angle stacks were also inverted and compared with the inverted volumes from the simultaneous inversion. This was carried out to determine the effectiveness of near and far-far elastic impedance volume in delineating hydrocarbon reservoirs. The inverted elastic volumes P-impedance $\left(Z_{P}\right)$, S-impedance $\left(Z_{S}\right)$, density $(\rho)$, near and far-far elastic and derived volumes lambda-rho $(\lambda \rho)$, mu-rho $(\mu \rho)$, Poisson's-ratio $(\sigma)$ reveal vertical and lateral continuity of the reservoirs identified (K01, N01 and P01) at $2179 \mathrm{~m}, 2484 \mathrm{~m}$ and $3048 \mathrm{~m}$, respectively. The delineated reservoirs showed good match with the sand tops away from the well control validated by a blind well test. The cross-plot of inverted $Z_{\mathrm{P}}$ from simultaneous inversion and well $Z_{P}$ gave correlation coefficient of $86 \%$ indicative of high quality inverted volume which will reduce exploration risk. The plot of inverted $Z_{\mathrm{P}}$ from simultaneous inversion and inverted far-far elastic volume reflected $82 \%$ correlation coefficient indicating that this method could be adopted in other fields with limited data and similar geological setting. Hence, the study has shown the efficacy of elastic volumes in delineating hydrocarbon reservoirs which can help locate optimum region for development wells.
\end{abstract}

Keywords Elastic impedance volume $\cdot$ Simultaneous inversion $\cdot$ Low frequency models $\cdot$ Near stack $\cdot$ Far-far stack

\section{Introduction}

Oluwakemi Y. Adesanya

kemmyadesanya@gmail.com

1 Department of Geosciences, Faculty of Science, University of Lagos, Lagos, Akoka, Nigeria

2 Earth Science and Reservoir Services, Chevron Nigeria Limited, 2 Chevron Drive, Lekki, Nigeria
Exploration for oil and gas has been an ongoing work in the Niger Delta Basin. Various tools have been used by past researchers to study its sedimentology, stratigraphy and economic prospects (Short and Stauble 1967; Weber and Daukoru 1975; Azeez 1976). However, the biggest breakthrough in petroleum and natural gas exploration came through the use of seismic method (Gadallah and Fisher 2009). Seismic method has been effective in identifying subsurface geological conditions favorable to the accumulation of hydrocarbon. 
However, seismic data have limited frequency content that might not be able to resolve thin layers, inconsistent low frequency for reservoir properties prediction coupled with low vertical resolution. Accurate delineation and assessment of quality of hydrocarbon reservoirs is vital for development planning to reduce risks in selecting new drilling locations (Simm and Bacon 2014; Adeoti et al. 2018). This would require the integration of seismic and well data for enhanced vertical and lateral resolution for quantitative interpretation. Seismic inversion is a sophisticated tool used by the oil and gas companies to integrate 3D seismic data with petrophysical measurements from wells to improve spatial resolution, reduce risk in exploration and enhance development plan (Neves et al. 2004; Avseth et al. 2005; Alfaro et al. 2007; Suslick et al. 2009; Adeoti et al. 2017). Since reflected seismic wave amplitudes are functions of acoustic/ elastic impedance, it becomes necessary to analysis seismic data stacked at various offset and angle of incidence ranges to exploit AVO (amplitude variation with offset)/ AVA (amplitude variation with angle) information in the data. Simultaneous inversion is capable of converting several angle stacks to elastic parameters which are capable of discriminating lithology and pore fluids within the reservoirs (Lavergne and Willm 1977; Lindseth 1979; Torres and Sen 2004; Hampson et al. 2006; Prskalo 2007; Jason 2013) while the elastic inversion converts specified angle stack to provide additional measurement which will improve the identification of hydrocarbon bearing reservoirs (Aki and Richards 1980; Connolly 1999 and Yilmaz 2002; Veeken and Da Silva 2004). There are several inversion techniques that could be adopted to invert seismic data to qualitative estimates of elastic parameters, but all require some prior information to constrain the inversion (Aki and Richards 1980; Sheriff 1992; Connolly 1999; Yilmaz 2002; Veeken and Da Silva 2004; Chopra and Marfurt 2005; Filippova et al. 2011; Adekanle and Enikanselu 2013). The inability of the traditional seismic data to properly delineate hydrocarbon reservoirs from subtle seismic features in 'Sandfish' field located offshore, Niger Delta informed the use of simultaneous and elastic impedance inversion to estimate elastic volumes and derived reservoir properties away from well locations. This would assist in delineating the hydrocarbon prospect and optimizing development plans in the study area.

\section{Geology of the study area}

The study area 'Sandfish' field falls within Niger Delta and covers about $614.4 \mathrm{~km}^{2}$ (Fig. 1). The Niger Delta province in the Gulf of Guinea basin is a major focus for exploration in West Africa. It is located at the southeastern end of Nigeria, bordering the Atlantic Ocean and extends from about latitudes $4^{\circ} 00^{\prime}$ to $6^{\circ} 00^{\prime} \mathrm{N}$ and longitudes $3^{\circ} 00^{\prime}$ to $9^{\circ} 00^{\prime} \mathrm{E}$
(Nwachukwu and Chukwura 1986). The Niger Delta region (Fig. 2) is known for its proficiency in hydrocarbon production among the sedimentary basins in Nigeria. The three major stratigraphic units recognized in the Niger Delta oil and natural gas province are the Akata, Agbada and Benin Formations (Short and Stauble, 1967). It has one petroleum system known as Tertiary Niger Delta (Akata-Agbada) and covers about 300 000 km² $^{2}$ (Evamy et al. 1978; Stacher 1995; Kulke 1995; Ekweozor and Daukoru 1984). The Delta began developing in the Eocene with accumulated sediments of over 10-km thickness (Kaplan et al. 1994). The primary source rock was identified as the upper Akata formation, the marine shale facies of the delta, with possible contribution from interbedded marine shale of the lowermost Agbada formation (Fig. 2). Oil is produced from sandstone facies within the Agbada formation; however, Turbidite sand in the upper Akata formation is a potential target in deep water offshore and possibly beneath currently producing intervals onshore (Short and Stauble 1967; Doust and Omatsola 1990; Tuttle et al. 1999).

\section{Theoretical concept}

Inversion of seismic data for elastic parameters involves two main stages: (1) estimate the reflectivity as a function of incidence angle for each point at the subsurface, and (2) inverting the reflectivity to estimate the corresponding elastic parameters in accordance to some mathematical models. The Aki-Richard (1980) approximate equation of Zoeppritz formula expressed in Eq. (1) was used in this study. This was used because it allows the estimation of three parameters $\left(Z_{P}\right.$, $Z_{S}$ and $\rho$ ) from which these elastic parameters other reservoir properties were derived. The reflection coefficient $\left(\mathrm{R}_{\mathrm{pp}}\right)$ was obtained from the linear combination of the three elastic parameters P-wave velocity, S-wave velocity and density. The approximation of the Zoeppritz's equation is only valid for small angles, and it assumes a horizontal layered earth model (Aki and Richards 2002).

$R_{\mathrm{pp}}(\theta) \approx A+B \sin ^{2} \theta+C \sin ^{2} \theta \tan ^{2} \theta$

, where $R_{\mathrm{pp}}(\theta)=$ reflection coefficient at a given angle; $\theta=$ average of the incidence and transmission angles at a plane reflecting interface; $A=$ Intercept; it's the normal incidence reflection coefficient; $\mathrm{B}=\mathrm{AVO}$ Gradient; it describes the variation at intermediate offsets.

\section{Methodology}

\section{Data gathering}

The data set used in this study was obtained from Chevron Nigeria Limited with permission from the Department of 


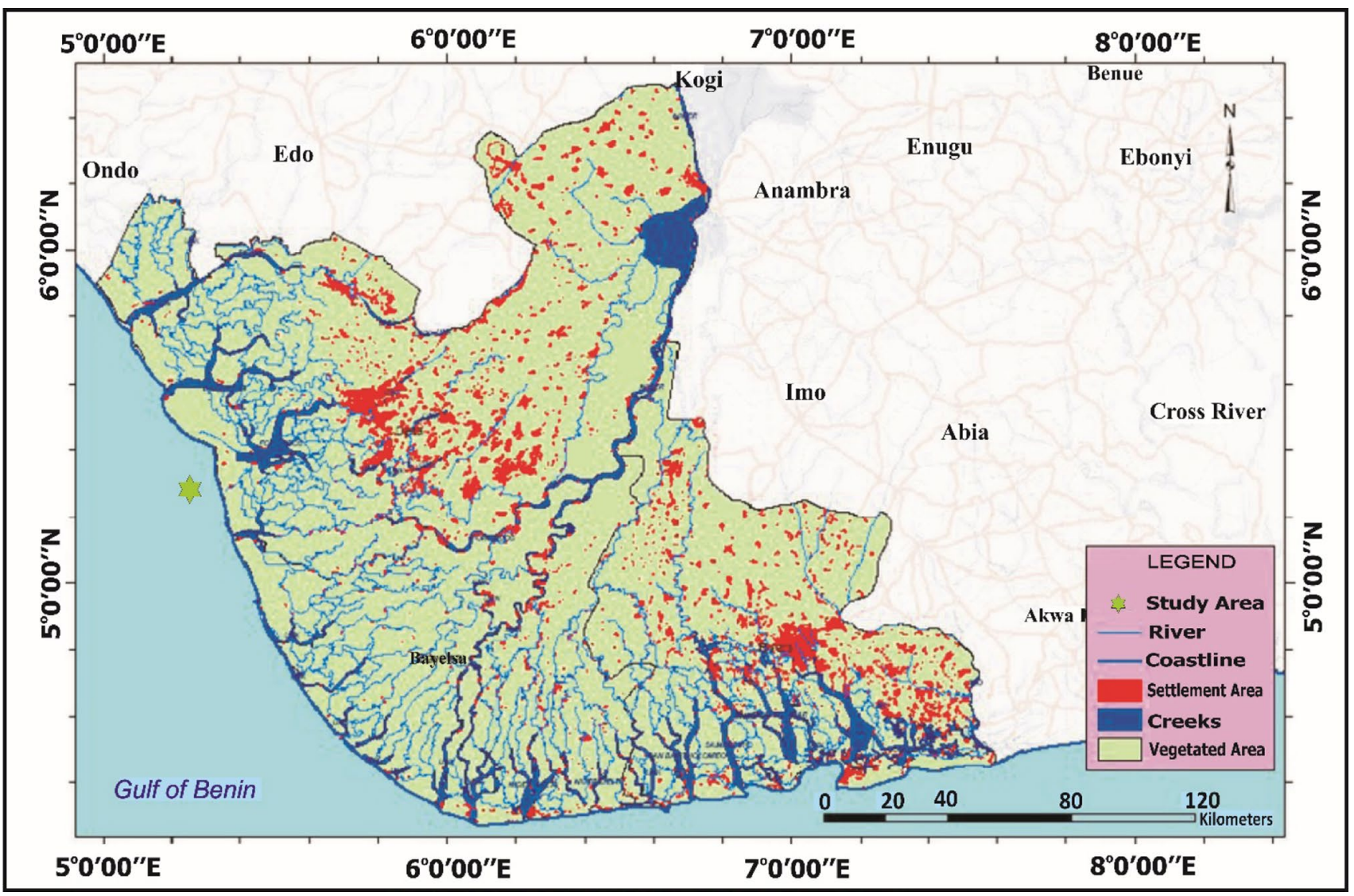

Fig. 1 Map of Niger Delta showing 'Sandfish’ field (reproduced from Adeoti et al. 2017)

Petroleum Resources (DPR). This includes 3D seismic data of five angles stacks ranging from (6 to $\left.42^{\circ}\right)$ with four wells (Sfn-01, Sfn-02 and Sfn-05). The seismic data with bandwidth frequency range of (6-55) $\mathrm{Hz}$, sampled at $4 \mathrm{~ms}$ and covering in lines $(10,242-11,061)$ and cross lines $(101$, $739-131,747$ ) with bin spacing of $25 \mathrm{~m}$ by $1 \mathrm{~m}$, respectively, as presented in Fig. 3. Three wells (Sfn-01, Sfn-02, Sfn-05) with the logs (P-sonic, S-sonic, density, porosity, gamma ray, resistivity and water saturation and check-shots) were used in this study. The check-shots from wells (Sfn-01, Sfn-02, Sfn-05) were used to establish the time-depth relation. Sfn-04 was used to validate inverted volume away from well control as a blind test. The interpreted horizons (E01, K01, N01 and P01) of the range 1500-2450 ms guided the inversion. The flow chart of the various steps adopted in this study is shown in Fig. 4.

\section{Well log and AVA analysis}

The petrophysical logs (P-sonic, S-sonic, gamma ray, resistivity, water saturation, density and neutron porosity) were used to identify the reservoirs. The P-sonic, S-sonic and density $\operatorname{logs}$ were used to generate $\mathrm{Z}_{\mathrm{P}}$ and $\mathrm{Z}_{\mathrm{S}} \operatorname{logs}$ while the combination of gamma ray, resistivity and water saturation logs were used for qualitative interpretation which involved the picking of sand tops at the target reservoirs. The checkshots were used to generate synthetic seismograms used for the seismic to well tie. The plot of amplitude variation with angle of incidence at the (N01) reservoir was carried out to reveal the AVO/AVA class of the hydrocarbon bearing sand according to Rutherford and Williams (1989) and Castagna and Swan (1997).

\section{Simultaneous inversion}

Simultaneous inversion was carried out to invert the seismic data into elastic properties descriptive of target reservoirs (Berge et al. 2002; Pendrel et al. 2000; Jason 2013). During the inversion, five angle stacks were simultaneously inverted to $\mathrm{Z}_{\mathrm{P}}, \mathrm{Z}_{\mathrm{S}}$ and $\rho$ from which other reservoir properties were derived for quantitative interpretation according to Bacon et al. (2003); Contreras et al. (2006) and Adeoti et al. (2017). The angle stacks (6-12 ${ }^{\circ}$, $12-18^{\circ}, 18-26^{\circ}, 26-32^{\circ}$ and $32-42^{\circ}$ ) were tied to the wells 


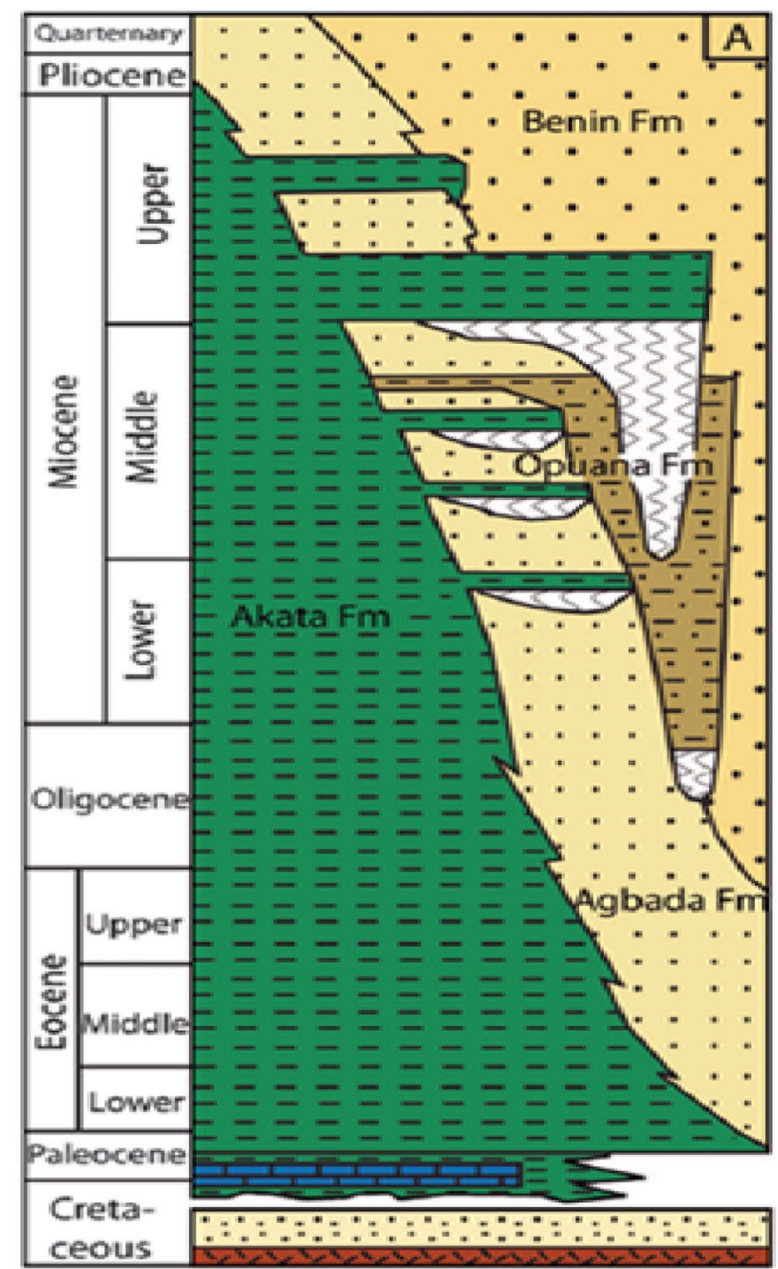

$\because$ Continental channel sands

$\because:$ Deltaic sedimentation

\section{$\because-\therefore$. Channel deposits}

Marine shale

Carbonates
Basement

\section{Erosion}

Fig. 2 Stratigraphic column showing different formations of Niger Delta (Corredor et al. 2005)

(Sfn-01, Sfn-02, Sfn-05) to ensure good correlation of events and for accurate extraction of wavelets from each of the angle stacks. The wavelets extracted from each of the angle stacks were used in the inversion. The low $(0-2 \mathrm{~Hz})$ frequency models built from the interpolation of filtered P-sonic, S-sonic and density $\operatorname{logs}$ were used to broaden the seismic frequency spectrum and to constrain the inversion. The sparse-spike inversion of Jason's RockTrace was used to iterate trial inversions until the model sufficiently matched the seismic data. The product of the simultaneous inversion $\left(Z_{P}, Z_{S}\right.$ and $\left.\rho\right)$ were used to derive Lambda-rho $(\lambda \rho)$ volume as stated in Eq. (2) for lithology and fluid discrimination in 'Sandfish' field (Bacon et al. 2003; Contreras et al. 2006). Other reservoir properties such as mu-rho $(\mu \rho)$, Poisson's-ratio $(\sigma)$ were determined in Adeoti et al. (2017).

Lambda - rho, $Z_{P}^{2}-2 Z_{S}^{2}=\lambda \rho$

The quality of the inverted volumes was checked by plotting the well $Z_{P}$ versus the inverted $Z_{P}$ from simultaneous inversion. This was further validated by the display of the inverted $\mathrm{Z}_{\mathrm{P}}$ from simultaneous inversion (band-limited) with inserted gamma ray $\log$ from wells (Sfn-04 and Sfn -05). 
Fig. 3 Base map of 'Sandfish' field showing seismic coverage and position of wells

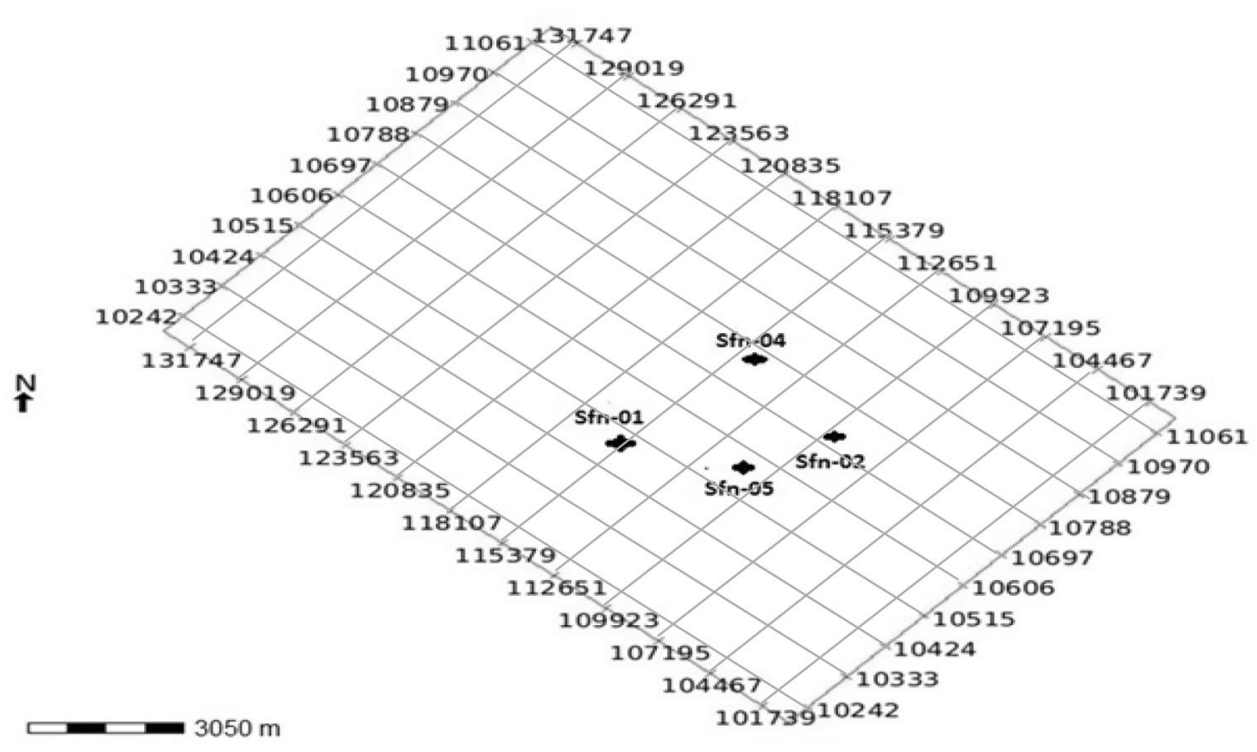

\section{Data}

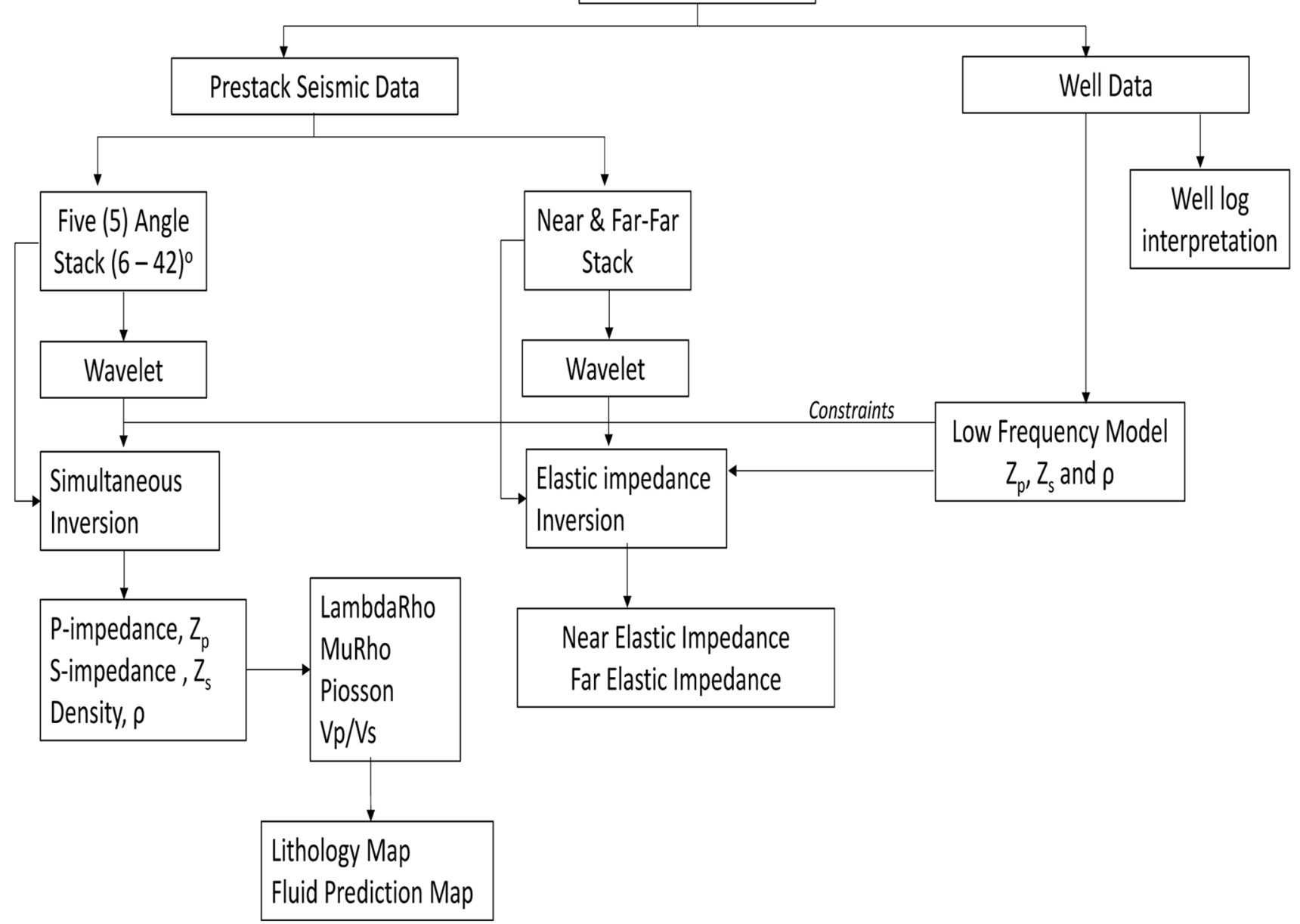

Fig. 4 Flow chart of the various steps adopted in this study 


\section{Elastic inversion (EI)}

EI provides a new approach to calibrate and invert incidence angle seismic data in a fashion analogous to zero-offset data (Karbalaali et al. 2013). The near (6-12 ${ }^{\circ}$ ) and far-far $\left(32-42^{\circ}\right)$ angle stacks were inverted to generate elastic volumes which revealed the variation of impedance with angle of incidence. Near and Far-far stacks were tied to wells (Sfn01, Sfn-02 and Sfn-05) for accurate wavelets extraction. The low frequency models, extracted wavelets and the four interpreted horizons (E01, K01, N01 and P01) were used in the inversion (Aki and Richards 1980; Connolly 1999; Yilmaz 2002; Nguyen and Larry 2008). The inverted elastic volumes generated were compared with the inverted $\mathrm{Z}_{\mathrm{P}}$ obtained from simultaneous inversion (Adeoti et al. 2017). This was carried out to determine the effectiveness of near and far-far elastic impedance volume in delineating hydrocarbon reservoirs in 'Sandfish.' The quality of the elastic inversion was checked by plotting $\mathrm{Z}_{\mathrm{P}}$ from simultaneous inversion with EI 37.2. Fig. 5.

\section{Results and discussions}

\section{Identification of reservoirs and AVA analysis}

The three reservoirs delineated are (K-01, N-01, and P-01) at the $2179 \mathrm{~m}, 2484 \mathrm{~m}$ and $3048 \mathrm{~m}$, respectively, with net to gross thickness of about $30 \mathrm{~m}$. The plot of amplitude variation with angle of incidence (Fig. 6) at the N-01 reservoir reflected typical class III AVO/AVA hydrocarbon bearing sand. The sands (K-01, and N-01 and P-01) were described as low impedance sands (Adeoti et al. 2017).

\section{Inversion quality check}

The cross-plot of inverted $\mathrm{Z}_{\mathrm{P}}$ from simultaneous inversion and well $\mathrm{Z}_{\mathrm{P}}$ (Fig. 7) gave correlation coefficient of $86 \%$ indicative of high quality inverted volume which will reduce exploration risk. The delineated reservoirs (Fig. 8) showed good match with the sand tops away from the well control validated by a blind well test.

\section{Derived Reservoir (Lambda-rho) Volume from Simultaneous Inversion}

Figure 9 is the Lambda-rho volume derived from the combination $\mathrm{Z}_{\mathrm{P}}$ and $\mathrm{Z}_{\mathrm{S}}$ of simultaneous inversion. It shows

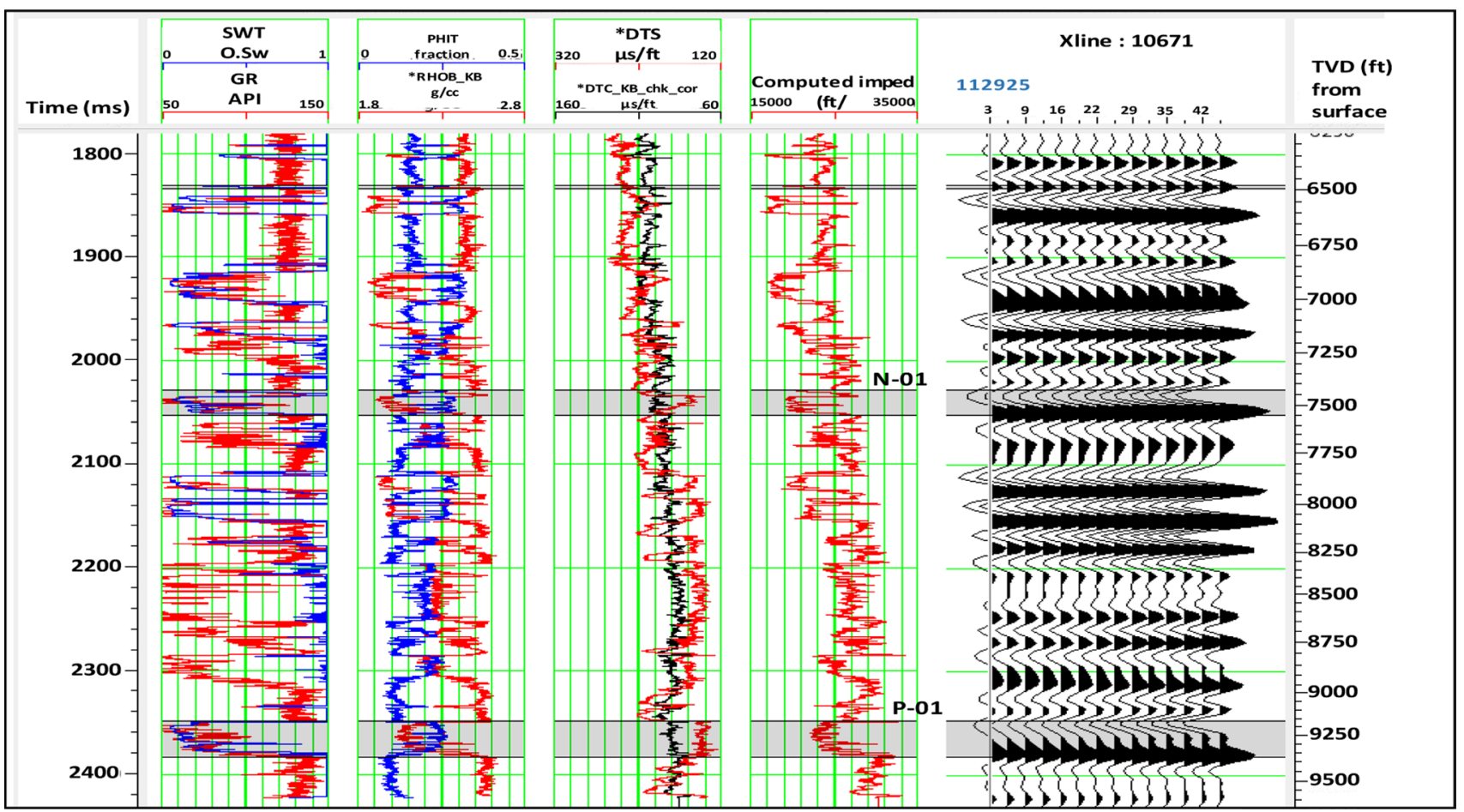

Fig. 5 Comparison of N-01 and P-01 reservoirs from Sfn-05 with seismic amplitudes variation at the intervals of interest (Adeoti et al. 2017)

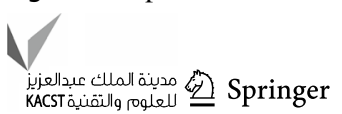




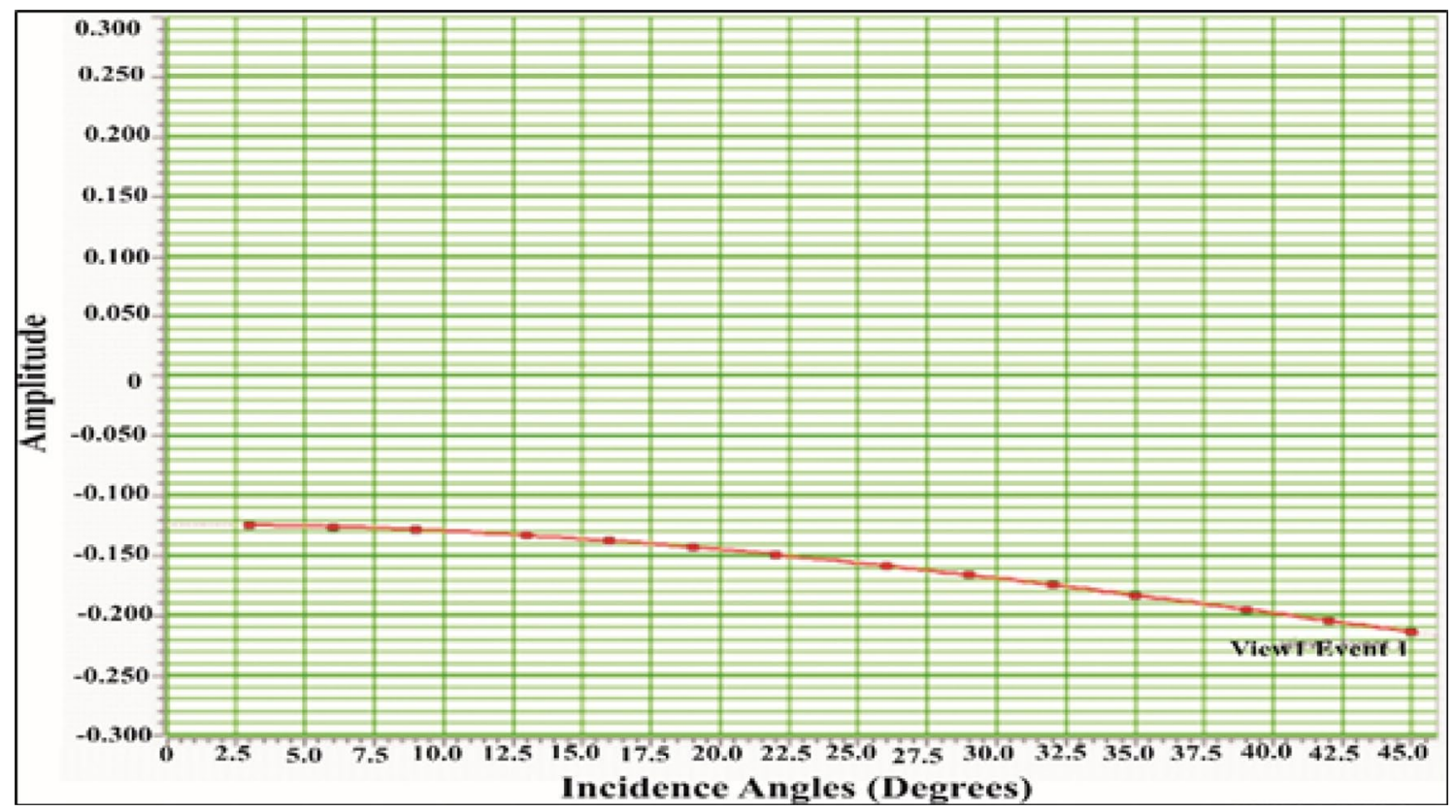

Fig. 6 Plot of amplitude reflection coefficient at N-01 reservoir versus angle of incidence (Rutherford and Williams 1989) demonstrated by Adeoti et al. (2017)

Fig. 7 Cross-plot of inverted $\mathrm{Z}_{\mathrm{P}}$ from simultaneous inversion and well $\mathrm{Z}_{\mathrm{P}}$ (Adeoti et al. 2017)

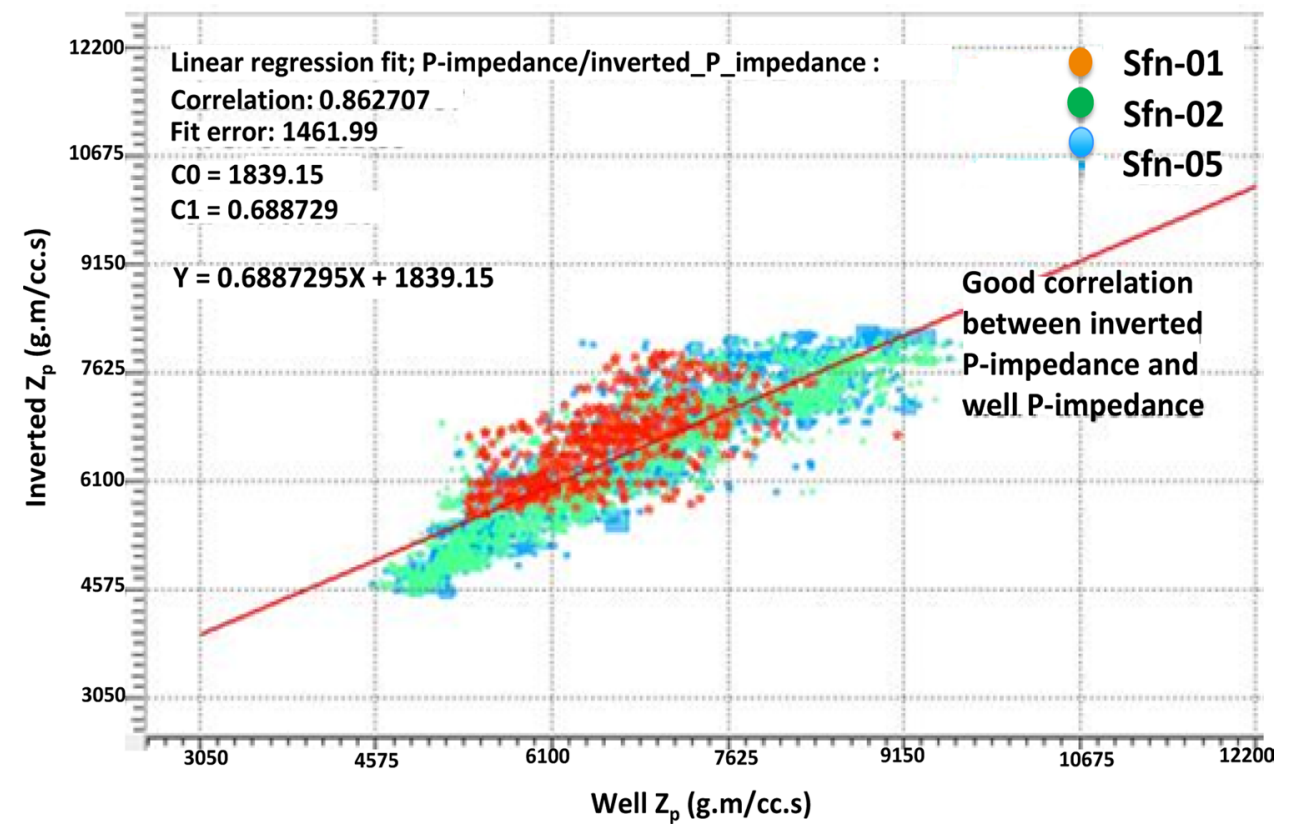

high resistivity response from the overlain resistivity log coinciding with low lambda-rho (yellow to red). The low lambda-rho indicates presence of hydrocarbon in the delineated sand. This shows that Lambda-rho is a good lithofluid discriminator in area of investigation.

\section{Elastic impedance volume}

Figure 10 is the EI 9.2 (full-bandwidth) which shows the gradual increase in impedance with depth, low impedance (yellow to red) indicates hydrocarbon bearing sands 


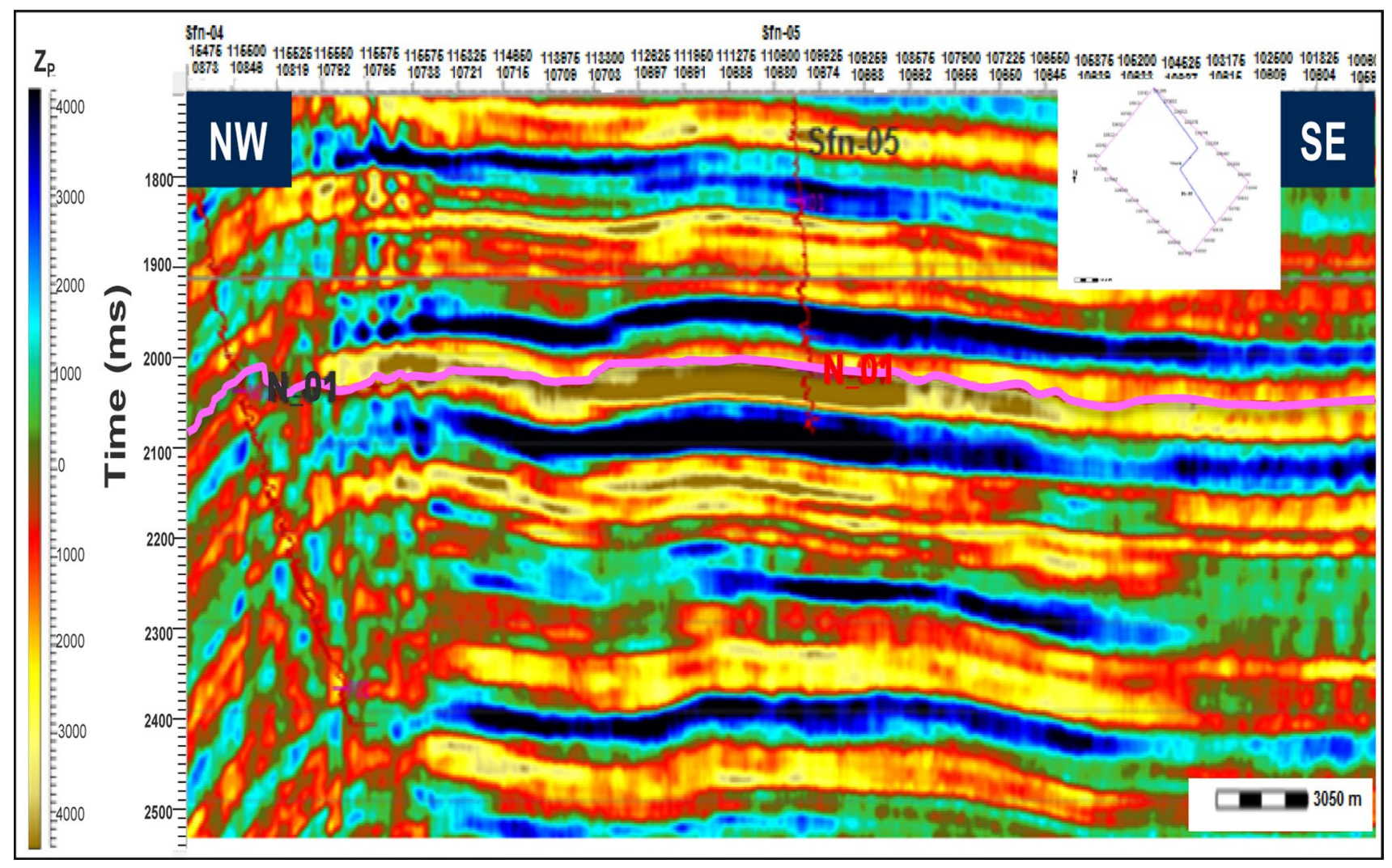

Fig. 8 Inverted $Z_{P}$ from Simultaneous inversion with inserted gamma ray log from Sfn-04 and Sfn-05 (Adeoti et al. 2017)

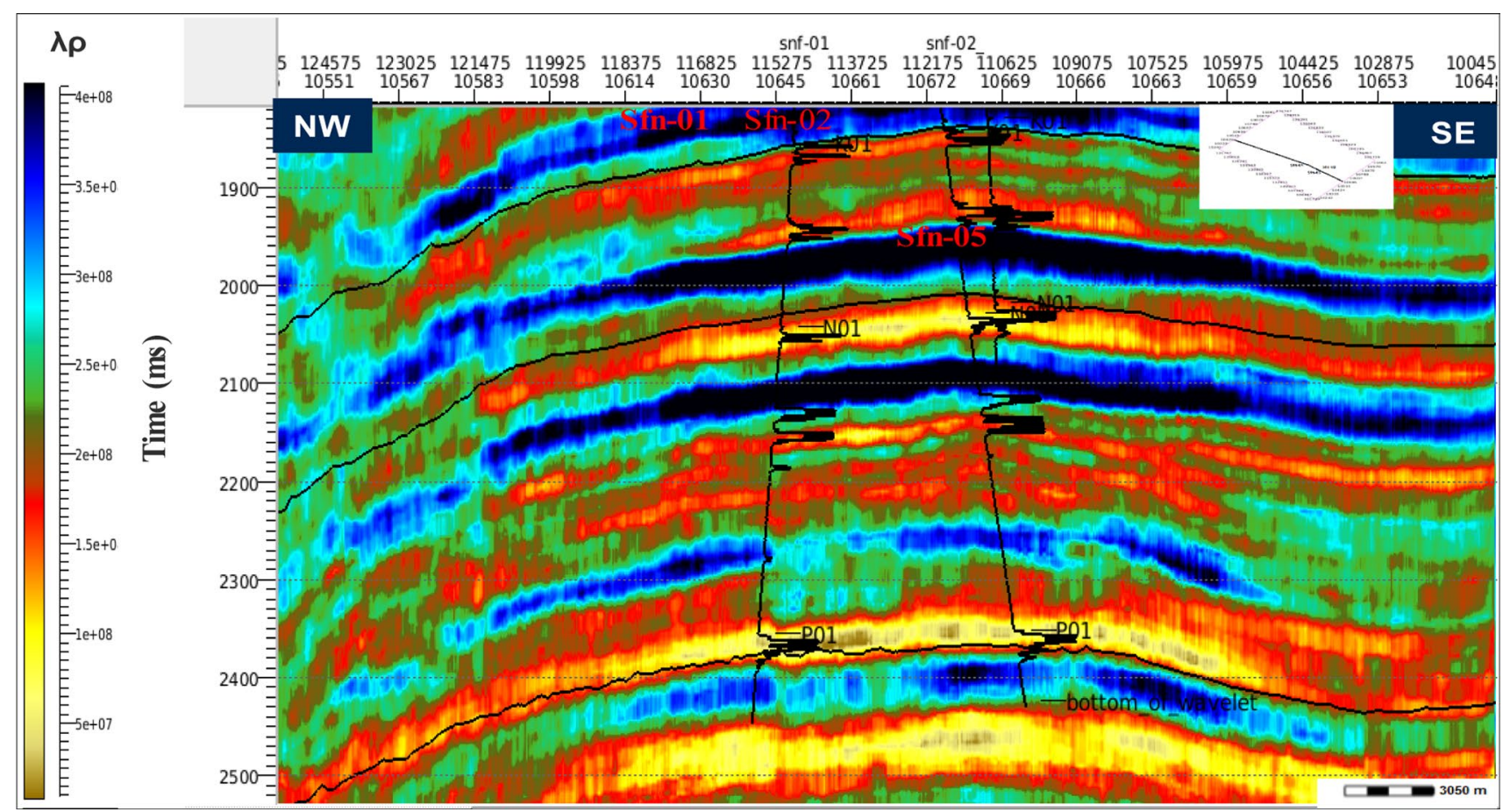

Fig. 9 Lambda-rho with overlain resistivity $\log$ (Adeoti et al. 2017)

1

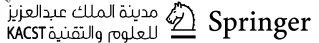




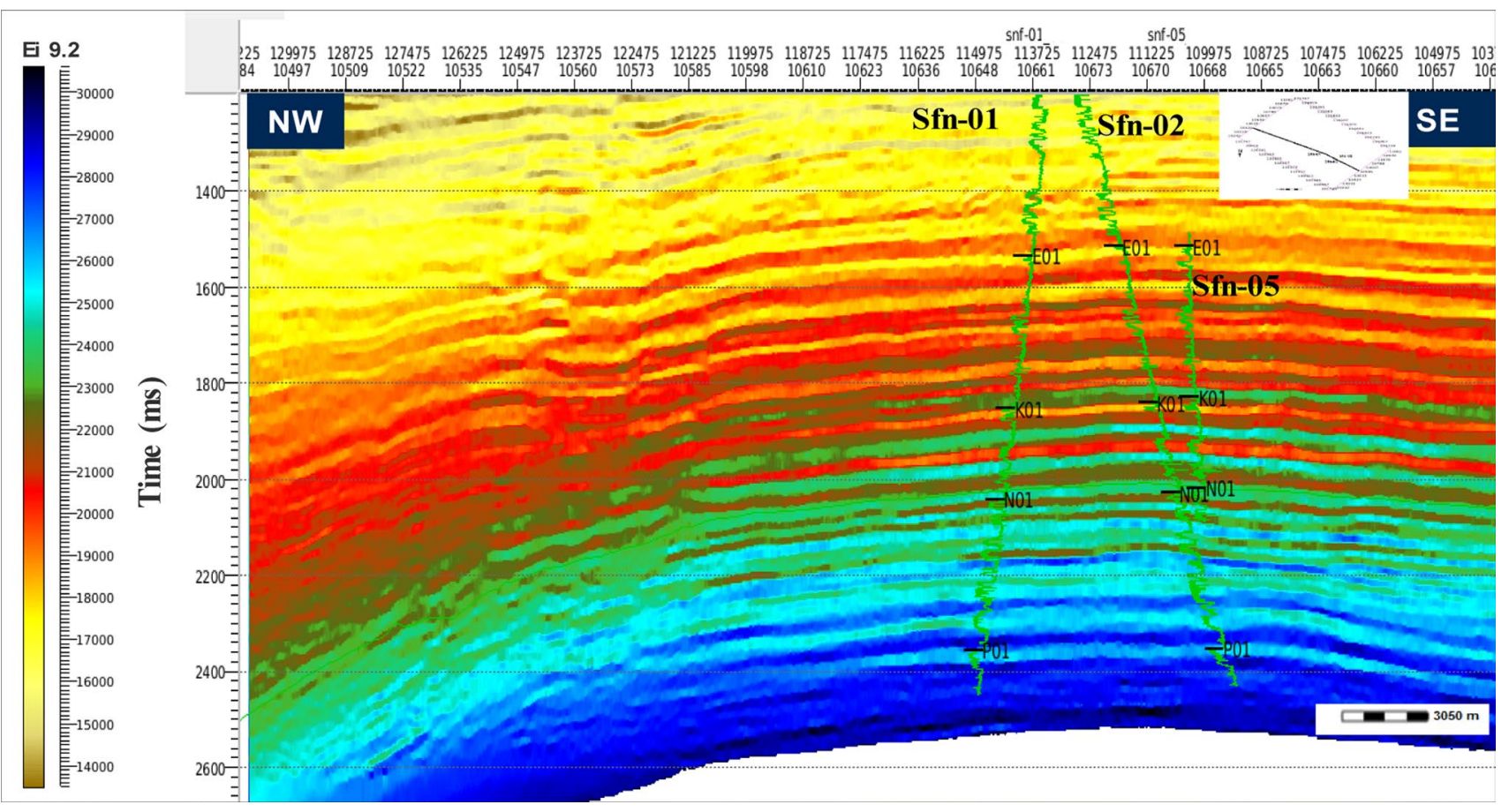

Fig. 10 Inverted EI 9.2 (full-bandwidth) with inserted gamma ray log

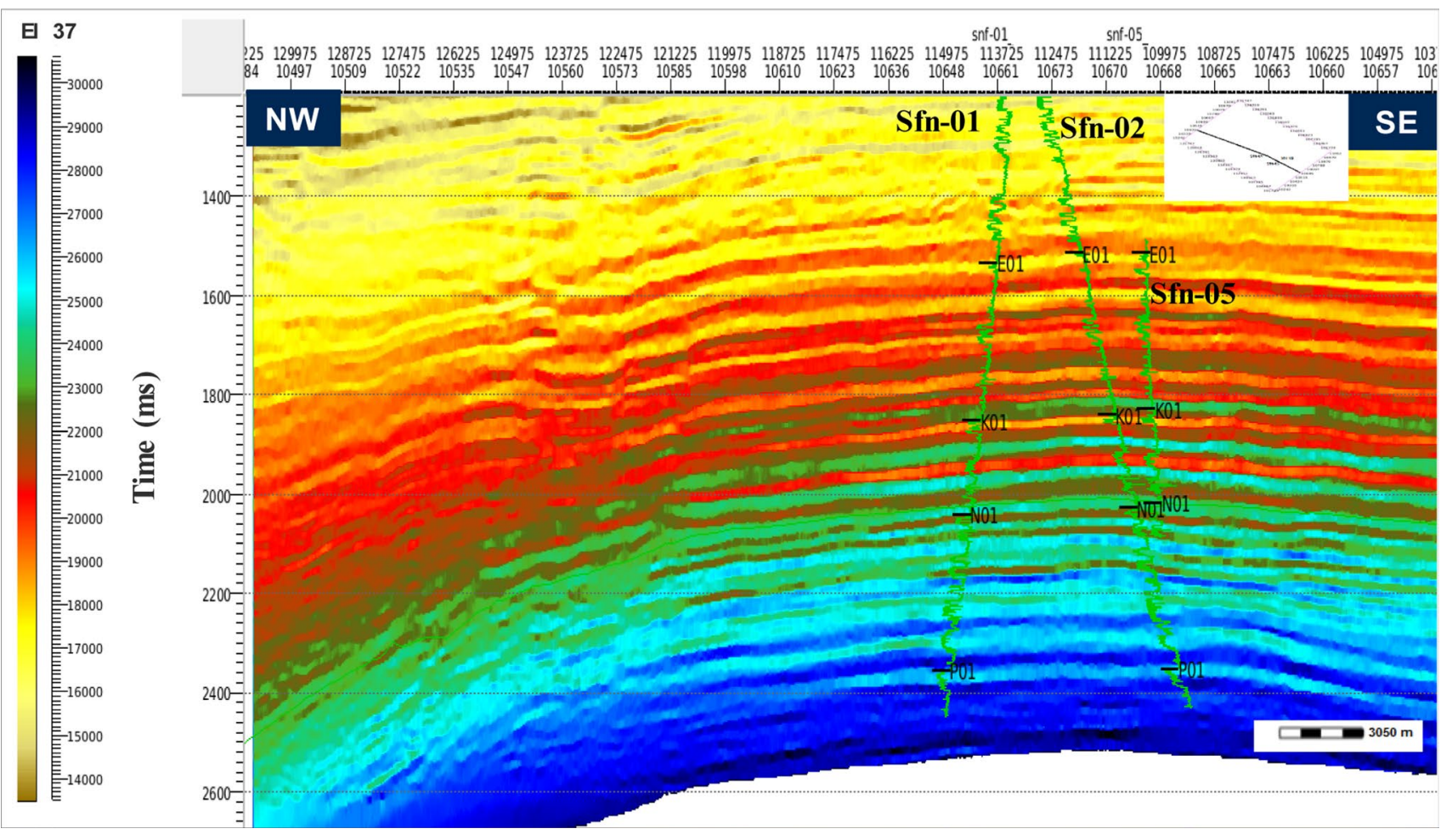

Fig. 11 EI 9.2 (band-limited) with inserted gamma ray log 


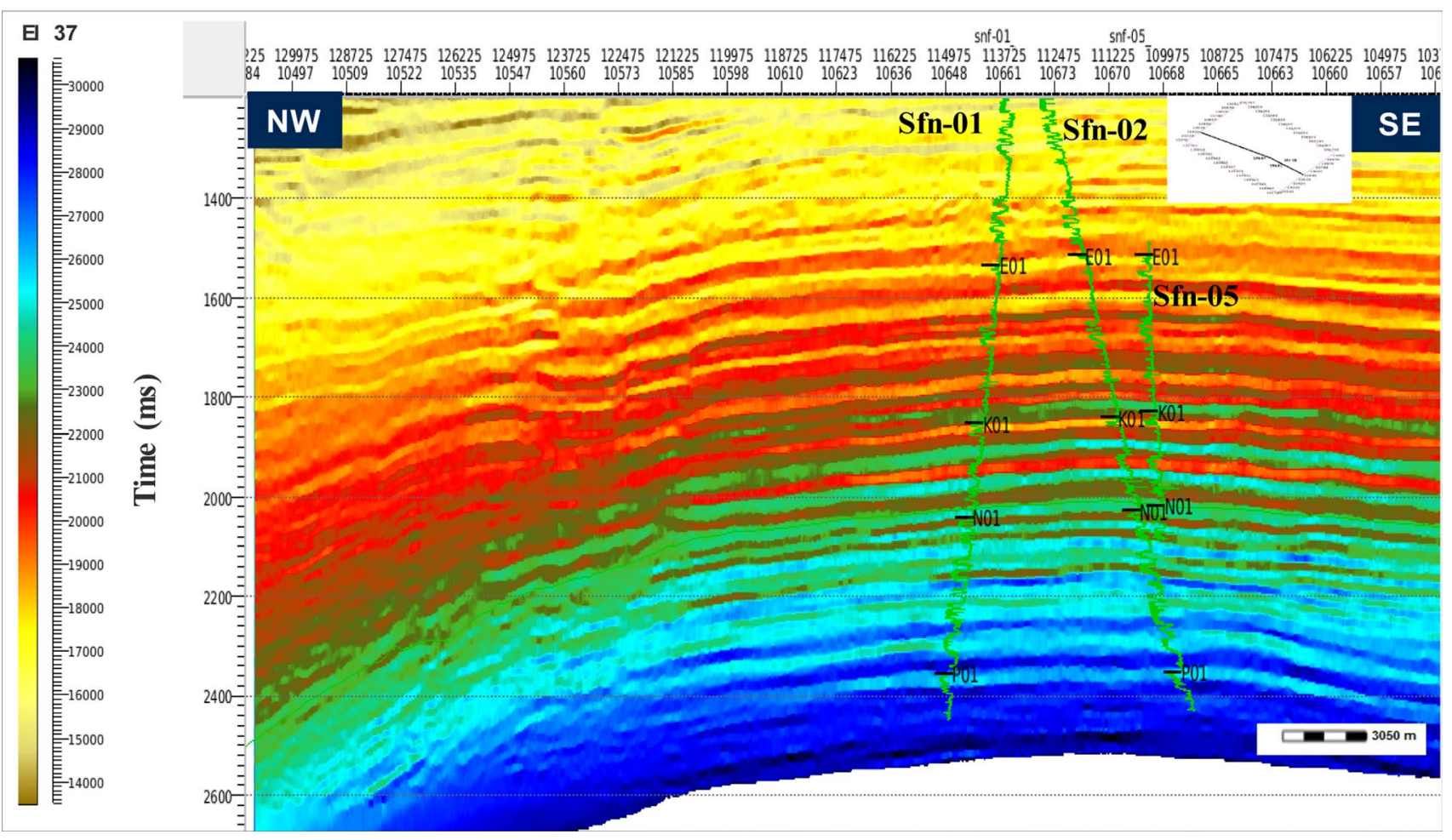

Fig. 12 EI 37.2 (full-bandwidth) with inserted gamma ray log

(K01 and N01) having good match with the low gamma ray response. The EI 9.2 (band-limited) is displayed in Fig. 11, the high impedance (blue) indicates background shale while the low impedance (yellow to red) depicts hydrocarbon bearing sands which has good match with the identified sands from the gamma ray curve. Figure 12 is the EI 37.2 (full-bandwidth) which gradually increases with depth, the low impedance (yellow to red) indicates hydrocarbon bearing sands (K01 and N01) with high match with the low gamma ray response. The EI 37.2 (band-limited) displayed in Fig. 13 shows high impedance (blue) as background shale while the low impedance (yellow to red) indicates hydrocarbon bearing sands which have high match with the sands from the gamma ray curve. The reservoirs are more evident on the EI 37.2 than on EI 9.2 because far-far angle stack is more sensitive to changes in fluid saturation (Connolly 1999). Figure 14.

\section{Comparison of simultaneous with elastic impedance volume}

The plot of inverted $\mathrm{Z}_{\mathrm{P}}$ from simultaneous inversion and inverted far-far elastic volume (Fig. 15) reflected $82 \%$ correlation coefficient indicating that this could be adopted in other fields with limited data but with similar geological setting.
Figures (15 and 16) show the correlation of inverted $\mathrm{Z}_{\mathrm{P}}$ from the simultaneous inversion from Adeoti et al. (2017) with the near and far-far elastic volumes (Full bandwidth and band-limited band). The elastic volumes showed good correlation at $1850 \mathrm{~ms}$ and $2050 \mathrm{~ms}$ which represent sands K01 and N01. The reservoirs are of low impedance (4880 to 6710$)$ g.m/cc.s) sands with corresponding low gamma response.

\section{Uncertainty and limitations}

The approximation of the Zoeppritz's equation adopted in this research is only valid for small angles, and it assumes a horizontal layered earth model (Aki and Richards 2002). The Zoeppritz's equations are no longer sufficient if we are to include anisotropy in our model.

\section{Conclusion}

Gamma ray response below the 70-API point is classified as sand while response greater than 70-API is classified as shale. High resistivity response with neutron-density overlay and low water saturation response were used in the picking of sand tops of identified reservoirs (K01, N01 and P01) at 2179 m, $2484 \mathrm{~m}$ and $3048 \mathrm{~m}$, respectively. The AVO/AVA 


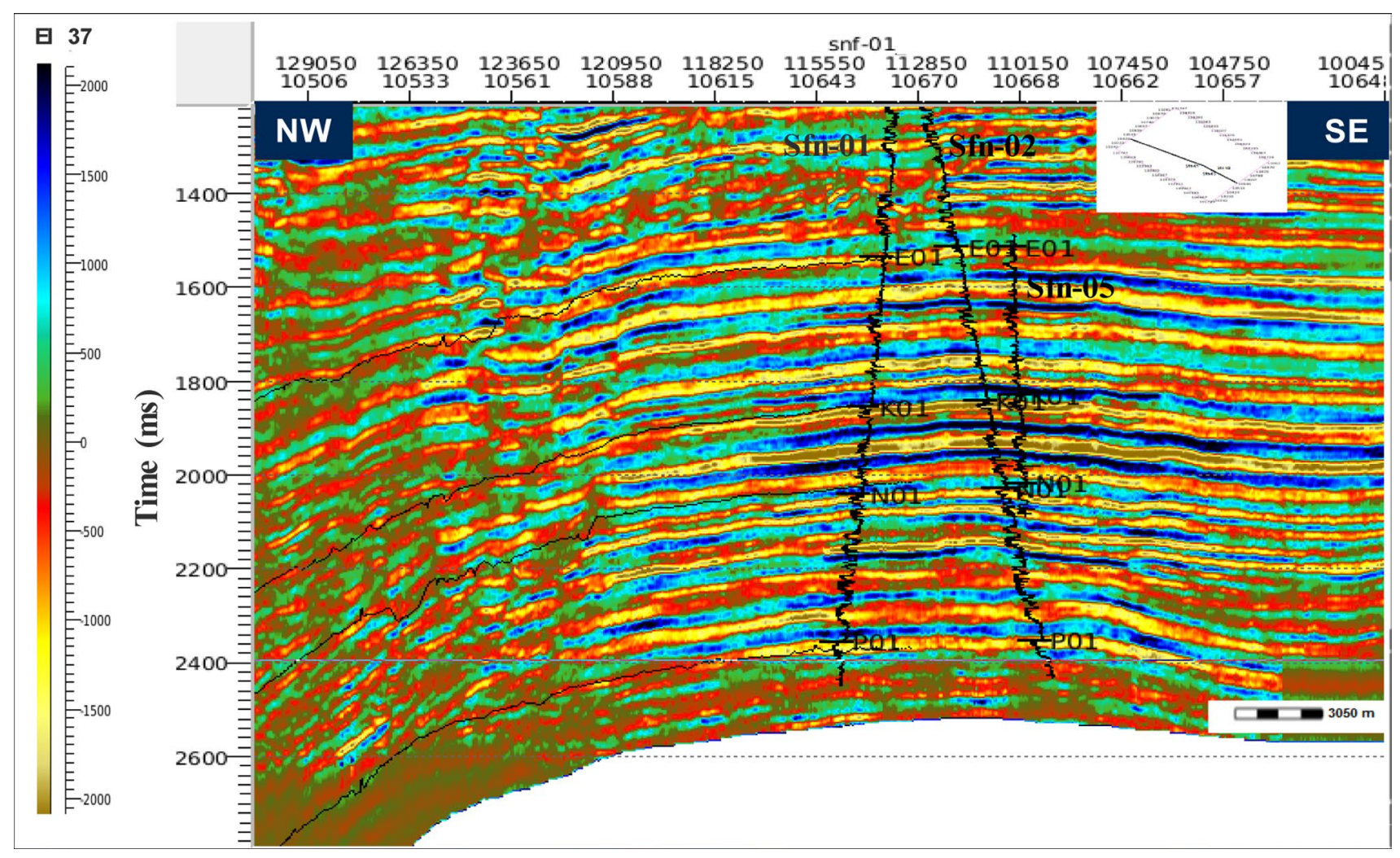

Fig. 13 EI 37.2 (band-limited) with inserted gamma ray log

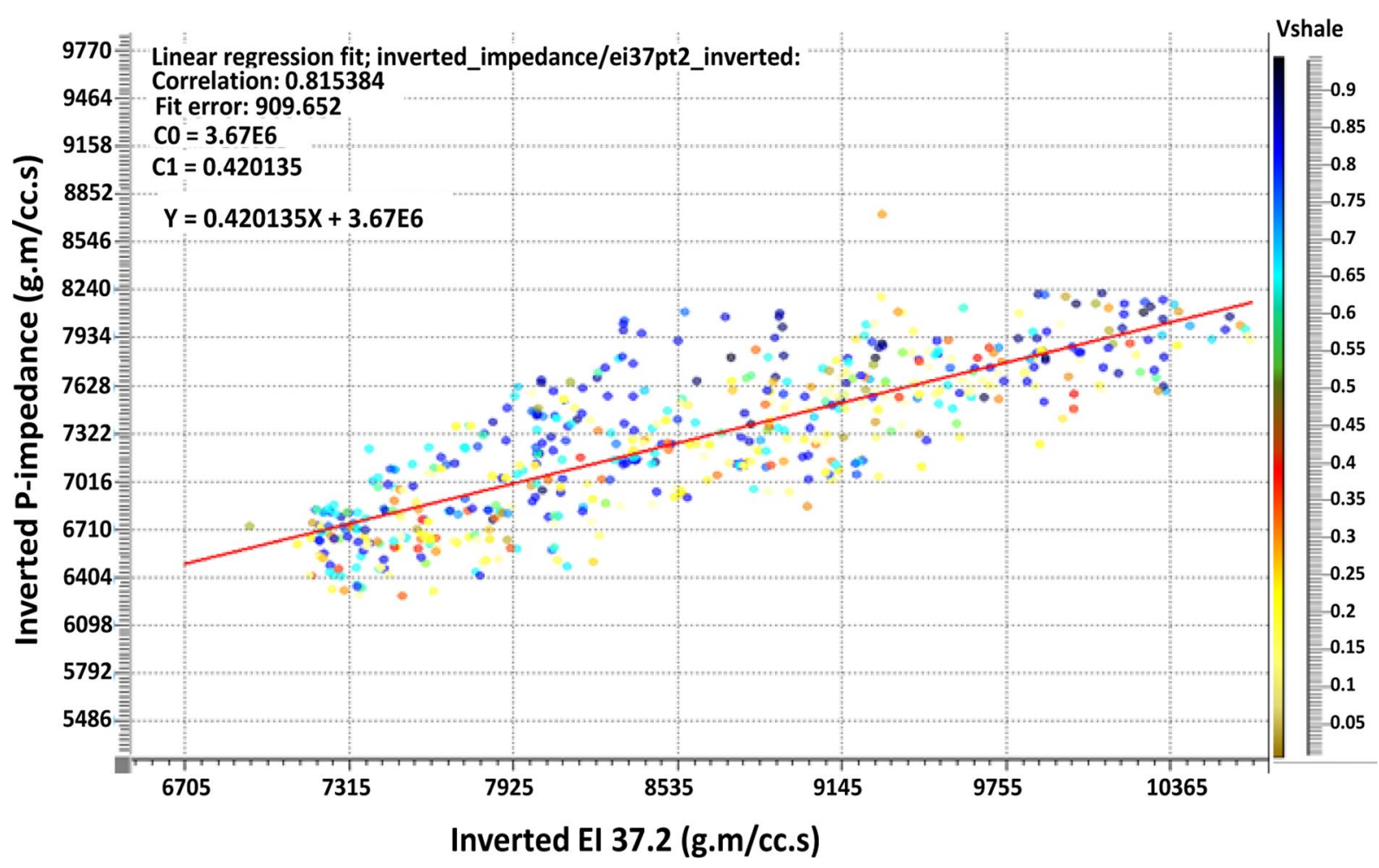

Fig. 14 Plot of inverted $Z_{P}$ from simultaneous inversion and inverted far-far elastic volume 


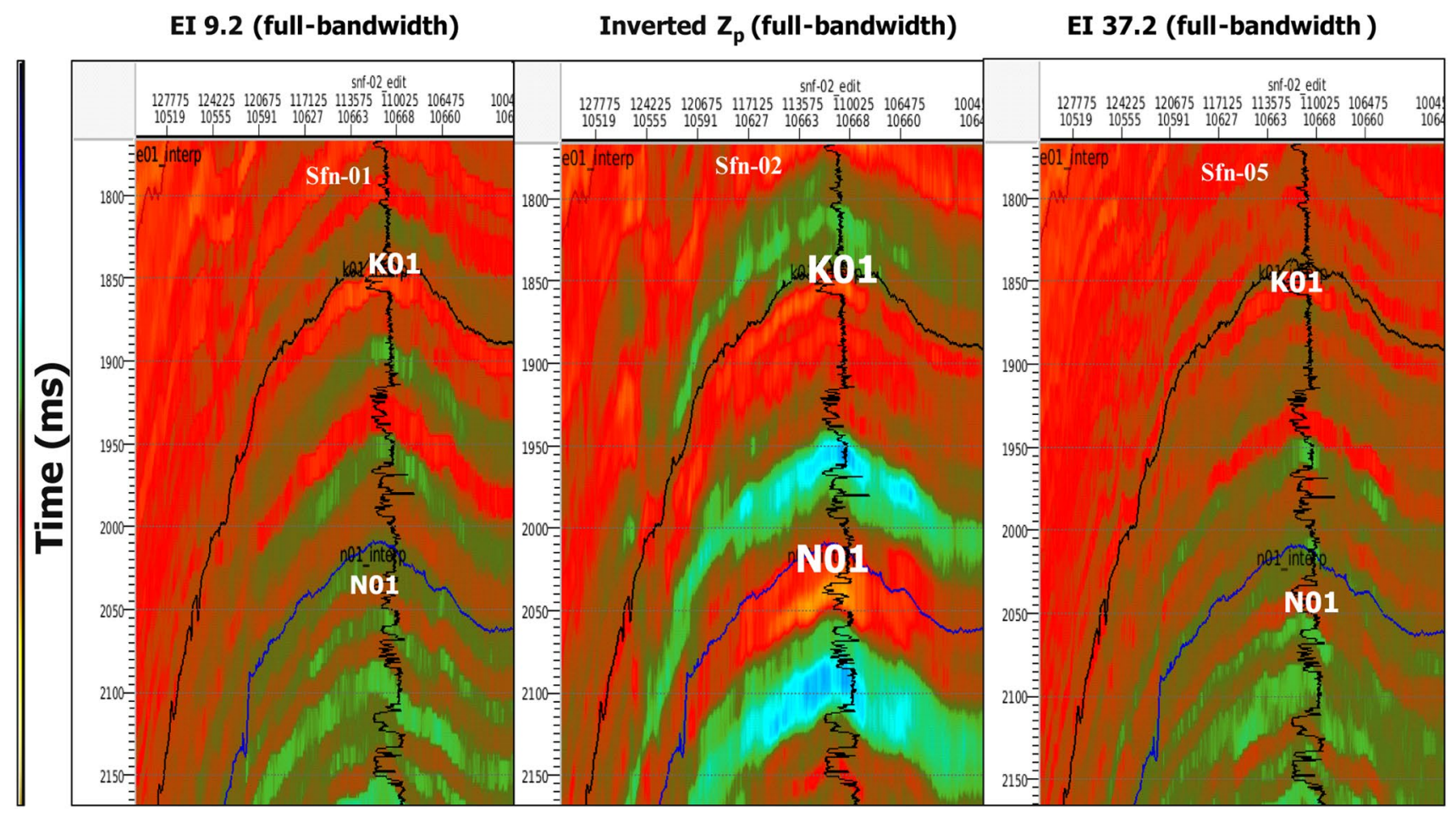

Fig. 15 Comparison of EI 9.2, inverted $Z_{P}$ and EI 37.2

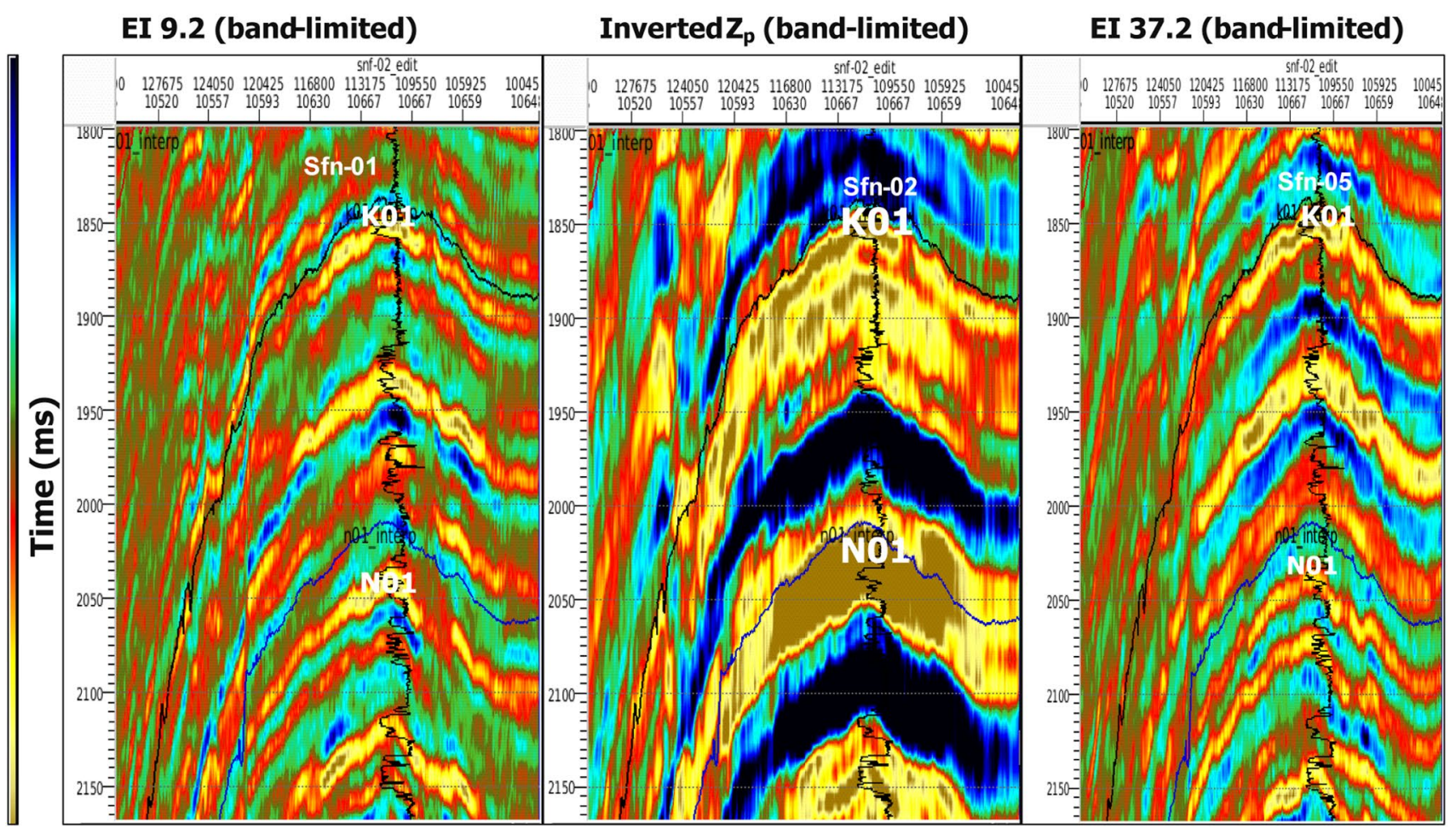

Fig. 16 Comparison of EI 9.2, inverted $Z_{P}$ and EI 37.2 
analysis which has proven effective in discriminating fluids in reservoirs agreed with the plot of amplitude reflection variation at $\mathrm{N}-01$ reservoir versus angle of incidence according to Rutherford and Williams (1989). The plot reflected class III AVO/AVA hydrocarbon bearing sand as demonstrated by Adeoti et al. (2017). The cross-plot of inverted $Z_{P}$ from simultaneous inversion and well $\mathrm{Z}_{\mathrm{P}}$ gave correlation coefficient of $86 \%$ indicative of high quality inverted volume which will reduce exploration risk in the study area. The cross-plot of inverted $\mathrm{Z}_{\mathrm{P}}$ from simultaneous inversion and EI 37.2 gave correlation coefficient of $82 \%$ which shows that the technique could be adopted in region with limited data but with similar geological setting. Hence, the study has shown the efficacy of seismic inversion to delineate hydrocarbon bearing sands in 'Sandfish' Field, Niger Delta. The generated elastic volumes will reduce risk, enhance hydrocarbon discovery and optimize development plans in the study area.

Acknowledgements We are grateful to the Department of Petroleum Resources and Chevron Nigeria Limited for providing the data used for this study.

\section{Funding None.}

Open Access This article is licensed under a Creative Commons Attribution 4.0 International License, which permits use, sharing, adaptation, distribution and reproduction in any medium or format, as long as you give appropriate credit to the original author(s) and the source, provide a link to the Creative Commons licence, and indicate if changes were made. The images or other third party material in this article are included in the article's Creative Commons licence, unless indicated otherwise in a credit line to the material. If material is not included in the article's Creative Commons licence and your intended use is not permitted by statutory regulation or exceeds the permitted use, you will need to obtain permission directly from the copyright holder. To view a copy of this licence, visit http://creativecommons.org/licenses/by/4.0/.

\section{References}

Adekanle A, Enikanselu PA (2013) Porosity prediction from seismic inversion properties over 'XLD' field, niger delta. Am J Sci Ind Res 4(1):31-35

Adeoti L, Adesanya OY, Oyedele KF, Afinotan IP, Adekanle A (2017) Lithology and fluid prediction from simultaneous seismic inversion over Sandfish field, Niger Delta, Nigeria. Geosci J 3:1-10

Adeoti L, Allo OJ, Ayolabi EA, Akinmosin A, Oladele S, Oyeniran T, Ayuk MA (2018) Reservoir fluid determination from angle stacked seismic volumes in 'Jay' Field Niger Delta, Nigeria. J Appl Sci Environ Manag 22(4):453-458

Aki K, Richards PG (1980) Quantitative seismology. freeman, W. H. and Co San Francisco, p 557

Aki K, Richards PG (2002) Quantitative seismology, theory and methods, 2nd edn. University science Books, Sausalito, California, p 700
Alfaro JC, Corcoran C, Davies K, Pinda FG, Hampson G, Hill D, Howard M, Kapoor J, Kragh E (2007) Reducing exploration risk. Spring, pp 26-47

Avseth P, Murkerji T, Mavko G (2005) Quantitative seismic interpretation. Cambridge University Press, Cambridge, UK

Azeez O (1976) The Stratigraphy, Sedimentation and Structure of the Niger Delta. In: Kogbe CA (ed) Geology of Nigeria. Elizabethan Pub.Co, Lagos, pp 259-271

Bacon M, Simm R, Redshaw T (2003) 3-D Seismic Interpretation. Cambridge University Press, Cambridge, UK

Berge TB, Aminzadeh F, de Groot P, Oldenziel T (2002) Seismic inversion successfully predicts reservoir, porosity, and gas content in Ibhubesi field. Orange Basin, South Afr Lead Edge $21: 338-348$

Castagna JP, Swan HW (1997) Principles of AVO cross plotting. Lead Edge 16(4):337-342

Chopra S, Marfurt KJ (2005) Seismic attributes - a historical perspective. Geophysics 70(5):3-28

Connolly P (1999) Elastic Impedance. Lead Edge 18:38-452

Contreras A, Torres-Verdin C, Fasnacht T (2006) AVA simultaneous inversion of partially-stacked seismic amplitude data for spatial delineation of lithology and fluid units deep water hydrocarbon reservoirs in the central Gulf of Mexico. Geophysics 71(4):41-48

Corredor F, Shaw JH, Bilotti F (2005) Structural styles in the deepwater fold and thrust belts of the Niger Delta. AAPG Bull $89: 753-780$

Doust H, Omatsola E (1990) Niger Delta. In: Edwards PA, Santogrossi PA (eds) Divergent and Passive Margin Basins. American Association of Petroleum Geologists, Tulsa, USA, pp 239-248

Ekweozor CM, Daukoru EM (1984) Petroleum source bed evaluation of Tertiary Niger Delta-reply. Am Asso Petrol Geol Bull 68:390-394

Evamy BD, Haremboure J, Kamerling P, Knaap WA, Molloy FA, Rowlands PH (1978) Hydrocarbon habitat of Tertiary Niger Delta. Am Asso Petrol Geol Bull 62:277-298

Filippova K, Kozhenkov A, Alabushin A (2011) Seismic inversion techniques: choice and benefits. First Break 29:103-114

Gadallah MR, Fisher R (2009) Exploration Geophysics. Springer, Berlin Heidelberg, p 262

Hampson DP, Russell BH, Bankhead B (2006) Simultaneous inversion of pre-stack seismic data. Geohorizons, pp 13-17

Jason Geoscience Workbench (2013) Simultaneous AVA/AVO Inversion. Fugro-Jason, Netherlands

Kaplan A, Lusser CU, Norton IO (1994) Tectonic Map of the world, Panel 10. American Association of Petroleum Geologists, Tulsa

Karbalaali H, Shadizadeh SR, Ali Riahi M (2013) Delineating Hydrocarbon Bearing Zones Using Elastic Impedance Inversion: A Persian Gulf Example. Iran J Oil Gas Sci Tech 2(2):8-19. http:// ijogst.put.ac.ir

Kulke H (1995) Nigeria. In: Regional Petroleum Geology of the World Part II. In: Kulke H (ed) Africa, America, Australia and Antarctica Berlin. Gebrüder Borntraeger, pp 143-172

Lavergne M, Willm C (1977) Inversion of seismograms and pseudovelocity logs. Geophys Prospect 25:232-250

Lindseth RO (1979) Synthetic sonic logs: a process for stratigraphic interpretation. Geophysics 44:3-26

Neves FA, Mustafa HM, Rutty PM (2004) Pseudo-gamma ray volume from extended elastic impedance inversion for gas exploration. Lead Edge 23:536-540

Nguyen N, Larry F (2008) From angle stacks to fluid and lithology enhanced stacks. Hyderabad 41:1-5

Nwachukwu JI, Chukwurah PI (1986) Organic matter of Agbada formation, Niger Delta, Nigeria. Am Asso Petrol Geol Bull 70:48-55

Pendrel J, Debeye H, Pedersen-Tatalovic R, Goodway B, Dafour J, Bogaards M, Stewart R (2000) Estimation and Interpretation of $\mathrm{P}$ and $\mathrm{S}$ Impedance Volumes from Simultaneous Inversion

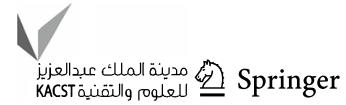


of P-wave Offset Seismic Data, Proceedings of the $70^{\text {th }}$ Annual International Meeting of Society of Exploration Geophysicists held in Calgary, Alberta, August 8-11:146-149

Prskalo S (2007) Application of relation between seismic amplitude, velocity and lithology in geological interpretation of seismic data. J Hung Geomath 2:51-68

Rutherford SR, Williams RH (1989) Amplitude versus offset variation in gas sands. Geophysics 54:680-688

Sheriff R (1992) Limitation on resolution of seismic reflections and geologic detail derivable from them. In: Payton CE (ed) Seismic stratigraphy-applications to hydrocarbon exploration. America Association of Petroleum Geologists, Tulsa, USA, pp 3-14

Short KC, Stauble A (1967) Outline geology of Niger Delta. Am Assoc Pet Geol 51:761-776

Simm R, Bacon M (2014) Seismic amplitude. Cambridge University Press, An interpreter's hand book

Stacher P (1995) Present understanding of the Niger Delta hydrocarbon habitat. In: Oti MN, Postma G (eds) Geology of Deltas. Balkema, Rotterdam, pp 257-267

Suslick SB, Schiozer D, Rodriguez MR (2009) Uncertainty and risk analysis in petroleum exploration production. Terrae 6(1):30-41

Torres C, Sen M (2004) Integrated Approach for the Petrophysical Interpretation of Post- and Pre-stack 3D Seismic Data, Well Log and Core Data, Geological Information and Production Data via
Bayesian Stochastic Inversion, Third Annual Report, Institute of Geophysics, Texas

Tuttle MLW, Charpentier RR, Brownfield ME (1999) The Niger Delta Petroleum System: Niger Delta Province, Nigeria, Cameroon, and Equatorial Guinea, Africa, United States Geological Survey, Open-File Report 99-50-H

Veeken PC, Da Silva M (2004) Seismic Inversion and some of their constraints. First Break 22(6):47-70

Weber KJ, Daukoru E (1975) Petroleum geology of the Niger Delta. Proceedings of the 9th World petroleum congress held in Tokyo, Japan, May 11-16, 209-221

Yilmaz O (2002) Seismic data analysis: processing, inversion. Society of Exploration Geophysicists Tulsa, And Interpretation of Seismic Data, p 2027

Publisher's Note Springer Nature remains neutral with regard to jurisdictional claims in published maps and institutional affiliations. 